\title{
INTERPRETAÇÃO DO ESTADO NUTRICIONAL DE SOJA PELO DRIS NO MATO GROSSO DO SUL
}

\author{
Shizuo Maeda \\ Orientador: Prof. Dr. Pedro Ronzelli Júnior
}

\begin{abstract}
RESUMO
Instrumentos para a caracterização nutricional das culturas são necessários no correto manejo da fertilidade do solo com vistas à melhoria da rentabilidade da atividade agrícola bem como da sustentabilidade do ambiente. Para tanto análises de solos e de folhas e interpretação de seus resultados, com bases em níveis críticos e faixas de concentração têm sido os critérios mais utilizados para embasar decisões. No entanto, interpretações de resultados analíticos feitas de forma isolada para cada nutriente e sua não hierarquização quanto a limitações nutricionais, apontadas e desligadas de possíveis efeitos de fatores como variedade, idade de tecido, bem como daqueles edafoclimáticos locais, restringem sua validade e a qualidade das recomendações eventualmente nelas embasadas. Nesse contexto o Sistema Integrado de Diagnose e Recomendação (DRIS) surge como alternativa aos referidos critérios interpretativos. Por outro lado, apesar de ser considerado menos suscetível aos referidos problemas que interferem nos demais critérios, também é influênciado por fatores que interferem em sua eficiência interpretativa e discriminatória. Há pois a necessidade de se minimizar tais efeitos por meio do desenvolvimento de "valores de referência" particularizados para as situações regionais para onde o DRIS venha a ser empregado. Com o objetivo de comparativamente caracterizar o estado nutricional de lavouras de soja da região Sul do Mato Grosso do Sul, por meio do critério das faixas de concentração para solo e folhas e do DRIS para folhas, amostras de solo, folhas e grãos de soja foram coletadas em lavouras comerciais, durante a safra 2000/2001. As de solo foram tomadas em número de 115 , durante os estádios $\mathrm{V} 1$ a $V 4$, nas entrelinhas, para cada uma das seguintes profundidades: 0-5, 5-10, 10-20, 0-20, e 20-40 cm. Os locais de amostragem corresponderam aos mesmos onde, posteriormente, tomaram-se amostras de folhas coletadas no estádio R1, da mesma forma, no estádio R8 foram coletadas amostras de grãos para avaliação de rendimento. Para o DRIS foram desenvolvidos valores de referência que foram validados por meio de sua aplicação em resultados de amostras foliares, que se apresentavam com sintoma de distúrbio nutricional. Para este caso os teores de nutrientes interpretados pelo DRIS geraram um diagnóstico de deficiência, apontando o $\mathrm{Mn}$ como o mais limitante dos nutrientes. Isso coincidiu com os sintomas visuais, demonstrando maior sensibilidade $e$ capacidade discriminatória do DRIS para a diagnose de distúrbios nutricionais. De modo geral o método de faixas de concentração apontou, nas folhas, N, Cu e P como os principais limitantes e no solo, Zn, K e P. Por outro lado os índices de diagnose do DRIS, calculados com base nos valores de referência desenvolvidos nesse trabalho. geraram resultados distintos daqueles obtidos a partir de dados compilados, demonstrando a necessidade de se desenvolver, de fato, valores de referência regionalizados.
\end{abstract}

\begin{abstract}
Methods for crop nutritional diagnosis are important tools to support decisions during the process of soil fertility management. Such procedures allow farmers to increase their chances to obtain profitability and to promote greater environmental sustainability of agricultural systems. For that purpose, particularly in Brazil, soil and leaf analysis have been the mostly used methods. However, it is well known that the resultant interpretation done in an isolated way for each nutrient by either the "critical levels" or the "concentration ranges" criteria are difficult to be organized under a hierarchy of limitations and are affected by several factors such as variety , tissue age, climate and soil properties, points which constitute restrictions for the validity and quality of recommendations based on them. In order to overcome such limitations some authors have proposed an alternative interpretation method, the Diagnosis and Recommendation Integrated System (DRIS), considered less susceptible but yet influenced by some factors in its discriminatory ability and efficiency of diagnosing plant nutrition status, and thus requiring the development of "reference values" for its regional application. The aim of this work was to characterize the nutritional status of soybean crops cultivated during the agricultural year of 2000/2001 in the southern portion of the state of Mato Grosso do Sul, Brazil, in order to allow comparisons between the leaf nutrient concentration ranges criteria and the DRIS. For that purpose soil and soybean grain and leaves were sampled in commercial areas, always from same sites. The soil was taken during $\mathrm{V} 1$ until $\mathrm{V} 4$ stage period at 5 depths $(0-5,5-10,10-20,0-20$, and $20-40 \mathrm{~cm})$, and the leaves were sampled during the R 1 stage. Regional "reference values" based on the leaf samples were established and validated by comparing DRIS interpretation with the visual diagnosis method. The efficacy and the ability to discriminate and to order nutritional problems were better for DRIS than for the other tested methods. This was demonstrated when data from a leaf sample presenting a classical Mn visual deficiency symptom led DRIS to rank Mn as the most limiting nutrient. Besides, for this case, data interpretation by the "concentration range" criteria gave N, Cu and $\mathrm{P}$ as the most deficient nutrients in the leaves, and $\mathrm{Zn}, \mathrm{K}$ and $\mathrm{P}$ in the soil. On the other hand, the difference between outputs given by DRIS based on published values and DRIS based on. regional values suggests that refinement of "reference values" may be beneficial when an 'improvement in DRIS accuracy is required.
\end{abstract}

Key-words: Glycine max, mineral nutrition, DRIS, Mato Grosso do Sul/Brazil. 